\title{
Principles of Christian Law
}

\author{
Mark HillQC \\ Centre for Law and Religion, Cardiff University; Faculty of Theology, University of Pretoria; \\ Dickson Poon School of Law, King's College London; Notre Dame University Law School, \\ Sydney
}

NORMAN DOE

Professor and Director, Centre for Law and Religion, Cardiff University

\begin{abstract}
A panel of experts has produced a Statement of Principles of Christian Law, drawn from an examination of their internal regulatory instruments. These principles are offered for further examination by comparative scholars of church law, as an expression of shared ecclesiology, and in furtherance of the ecumenical endeavour.
\end{abstract}

Keywords: Christian law, common principles, ecumenism, ecclesiology, World Council of Churches

The legal regulation of churches has achieved greater prominence in recent years. The study of Roman Catholic canon law has long been part of clerical formation, but that of other Christian traditions is less developed. Readers of this Journal will be familiar with the work of the Colloquium of Anglican and Roman Catholic Canon Lawyers. ${ }^{1}$ In November 2013 an invited symposium was convened at the Venerable English College in Rome. The participants comprised a panel of experts who attended in their personal capacities not as representatives of their denomination. They were selected for their expertise in the church law, order or polity ${ }^{2}$ of particular Christian churches, namely: Anglican, Baptist, Catholic, Lutheran, Methodist, Orthodox, Presbyterian and Reformed. ${ }^{3}$ The aim of the symposium was to explore critically the extent to

1 See M Hill et al, 'A decade of ecumenical dialogue on canon law', (2009) 11 Ecc LJ 284-328.

2 The expressions 'law', 'order' and 'polity' are variously used to describe the systems of internal regulation by which differing denominations govern themselves. For convenience, we use the term 'law' throughout this document as a shorthand embracing all three terms.

$3^{\dagger}$ The panel was convened by Professor Mark Hill QC, together with Professor Norman Doe. Its membership also comprised: Revd John Chalmers (former Moderator of the General Assembly of the Church of Scotland), Revd Ken Howcroft (former President of the Methodist Church in Great Britain), Aidan McGrath OFM (Secretary General of the Franciscan Order), Robert Ombres OP (Blackfriars Oxford, formerly Procurator General of the Dominican Order), Professor Leon van

$\dagger \quad$ The original version of this article was published with a publisher's error in footnote 3 . A notice detailing this has been published (doi: 10.1017/So956618X17000849) and the error rectified in the online PDF and HTML versions. 
which different Christian churches share common principles in their laws and other instruments of internal governance, and the ways in which these principles and instruments may contribute creatively to ecumenism.

Drawing on the pioneering work of Professor Norman Doe, ${ }^{4}$ the panel formed the view that there are principles of Christian law and church order common to the Catholic, Orthodox, Anglican, Lutheran, Methodist, Reformed, Presbyterian and Baptist traditions and that their existence can be factually established by empirical observation and comparison. Each Christian tradition contributes through its regulatory instruments to this store of principles, which have a strong theological content and are fundamental to their ecclesiological self-understanding. They have a living force and contain within themselves the possibility of further development and articulation. Cumulatively, they demonstrate a degree of unity between the churches, and may be deployed in the ecumenical endeavour to enhance fuller visible unity.

The Panel of Experts has continued to meet annually to discuss how its work might feed into that of the World Council of Churches (WCC), offering a legal insight into its Faith and Order Commission Paper No 214, 'The Church: towards a common vision' (2013). A juridical response drafted by the Panel was submitted to the WCC's Faith and Order Commission. ${ }^{5}$ In 2016, the Panel of Experts agreed a Statement of Principles of Christian Law. It now offers these principles (laid out verbatim below) for further discussion and reflection by the component churches and by others engaged in the ecumenical movement.

\section{SECTION I: CHURCHES AND THEIR SYSTEMS OF LAW, ORDER AND POLITY}

The word 'law' encompasses a variety of regulatory instruments and other norms including constitutions, canons, covenants, books of church order, and other polity documents.

den Broeke (Vrije Universiteit, Amsterdam), Professor Leo Koffeman (Protestant Theological University, Amsterdam), Professor Nikos Maghioros (Aristotle University, Thessaloniki), Anna Trônet (diocesan lawyer, Church of Sweden) and Revd Dr John Weaver (former Principal, South Wales Baptist College). It had the benefit of contributions from Fr Tony Currer (Pontifical Council for the Promotion of Christian Unity), Archbishop Sir David Moxon (Archbishop of Canterbury's Representative to the Holy See), Revd Marcus Walker (Associate Director, Anglican Centre in Rome), Revd Tim Macquiban (Methodist Church) and Revd Dr Peter Stevenson (Principal, South Wales Baptist College). Revd Dr Paul Goodliff (former Head of Ministry at the Baptist Union of Great Britain and Associate Fellow, Spurgeon's College London) joined the panel in 2016. The panel wishes to acknowledge the generous hospitality of the Venerable English College, Rome and its Rector Mgr Philip Whitmore, and His Excellency Nigel Baker, formerly HM Ambassador to the Holy See.

$4 \quad$ N Doe, Christian Law: contemporary principles (Cambridge, 2013).

5 The Panel of Experts meets next in Geneva in November 2017, at which time it is hoped to share its work with the Director of the WCC's Faith and Order Commission, Professor Odair Pedroso Mateus. 


\section{The institutional church}

1. A church as an institution may define itself by its autonomy, polity, and objects.

2. A church is a community which may be international, national, regional, or local.

3. A church has a distinct membership, or other body of persons associated with it, which may be organised in territorial or non-territorial units such as provinces, districts, or congregations.

4. A church is autonomous in its system of governance or polity.

5. A church has amongst its objects the advancement of the mission of Christ which includes proclaiming the Gospel, administering the sacraments, and serving the wider community.

6. Communion amongst the faithful is an essential quality of ecclesial life.

\section{The forms of ecclesial regulation}

1. Laws are found in a variety of formal sources including codes of canon law, charters and statutes, constitutions and bylaws, and books of church order.

2. Customs may have juridical force to the extent permitted by the law of a church.

3. Ecclesiastical quasi-legislation, which includes guidelines and codes of practice, is designed to complement formal law and consists of rules that are nevertheless prescriptive in form and generate the expectation of compliance.

\section{The servant law}

1. Church law and church order exist to serve a church in its mission and in its witness to the salvific work of Christ.

2. Laws contribute to constituting the institutional organisation of a church and facilitate and order its activities.

3. Theology may shape law and law may realise certain theological propositions in norms of conduct and behaviour.

4. Church laws should conform to the law of God, as revealed in Holy Scripture and by the Holy Spirit.

\section{The structure, effect and relaxation of norms}

1. Church laws principally deal with ministry, government, doctrine, worship, rites, admonition and discipline, and property.

2. Church laws consist of various juridical formulae, such as precepts, prohibitions, and permissions, and may be cast as principles and rules, rights and duties, functions and powers.

3. Laws may be binding or exhortatory. 
4. All members of a church are subject to its laws as are its component institutions, to the extent that the law provides.

5. Later laws may abrogate earlier laws.

6. Laws are prospective and should not be retrospective in effect unless this is clearly provided for in the laws themselves.

7. Laws should be clear, stable, and coherent.

8. A church may have in place a mechanism for the enforcement and vindication of the rights and duties of the faithful.

9. A law may be relaxed, by competent ecclesial authority, by means of dispensation, economy or other form of equity for the spiritual good of the individual and the common good of the ecclesial community.

\section{The interpretation of law}

1. Laws should be interpreted by reference to their text, context, and precedent.

2. A church has authority to interpret its own law.

3. For the interpretation of law, recourse may be had to the purposes of the law, the mind of the legislator, and the faith and practice of the church.

\section{SECTION II: THE FAITHFUL}

Some churches expressly use in their regulatory instruments the category 'member', others do not. However, each church has an identifiable group of the faithful associated with it. For the purposes of this section, the word membership denotes both juridical categories.

\section{The People of God}

1. The Christian faithful constitute the people of God.

2. All the faithful should be equal in dignity.

3. Baptism generates duties and rights for the faithful.

4. The faithful includes lay and ordained people.

\section{Church membership and others forms of belonging}

1. A church is made up of those incorporated into it in accordance with its proper laws and customs.

2. A church should serve, in appropriate ways, all who seek its ministry regardless of membership.

3. Membership in a church, for the purposes of participation in its government, may be based on any or all of: baptism; baptism and confirmation or other mature demonstration of faith; and such other conditions as may be prescribed by law. 
4. The names of persons belonging to a church may be entered on one or more rolls or other registers of membership subject to such conditions as may be prescribed by law.

5. Names may be removed from such rolls and registers in accordance with the law.

\section{The functions of the laity}

1. The law of a church should generally set out the basic rights and duties of all its members.

2. The laity should promote the mission of the church, and bear witness to the Christian faith through their lives in the world.

3. A lay person should engage in the collective ecclesial life, in proclaiming the Word of God, participating in worship, and receiving the sacraments.

4. Lay persons should maintain such Christian standards in their private lives as are prescribed by law.

5. Lay persons are encouraged to practise daily devotion, private prayer, Bible reading, and self-discipline, bringing the teaching and example of Christ into everyday life, upholding Christian values, and being of service to the church and wider community.

\section{Public ministry exercised by lay persons}

1. Public ministry, a gift of God, is the fulfilment of a function assigned formally in a church to an office or other position exercised under authority on behalf of that church in the service of its mission and witness to the Gospel.

2. The law should enable the laity to exercise public ministry in those offices and other positions lawfully open to them.

3. Lay persons may be admitted to such offices and positions provided they are suitable, qualified, selected, and admitted by competent ecclesial authority for such term as is prescribed by law.

4. Lay ministers and officers exercise such public and representative ministry within and on behalf of a church and perform such functions as may be prescribed and permitted by its law.

5. The authority to discipline, dismiss, or reappoint a lay minister or officer depends on, and its exercise must comply with, the law of the church.

\section{SECTION III: ORDAINED MINISTRY}

The churches set apart persons for ministry in a special rite, for most called ordination.

The following principles apply to ordained ministry and also address ecclesiastical offices which, depending on the church concerned, may be held by either ordained or lay persons. 


\section{Ordination}

1. Ordained ministry is divine in origin and persons are set apart for it.

2. A church may distinguish between different types of ordained minister.

3. Candidates for ordination must be called by God and by the church to ordained ministry.

4. Vocation to and suitability for ordained ministry are tested by the church through a process of selection, examination, and training by competent authority.

5. Persons are generally admitted to ordained ministry through ordination.

6. Ordination is administered by competent authority by means of the laying-on of hands and invocation of the Holy Spirit.

\section{Ecclesiastical offices}

1. An ecclesiastical office is a position constituted by law.

2. An ecclesiastical office exists independently of the person who occupies it.

3. An ecclesiastical office enables the discharge of functions of the particular ministry attaching to it.

4. An ecclesiastical office may be held by a person or persons with such qualifications as are prescribed by law.

5. An ecclesiastical office is filled by a variety of means, often by appointment or election.

6. The jurisdiction or other authority which attaches to an office is determined by or under the law.

7. Authority attaching to an office may be delegated to the extent provided by law.

8. The authority to exercise ecclesiastical office ceases upon lawful dissolution of the office, expiration of the stated term of office, attainment of the prescribed age limit, or the death, resignation, transfer, retirement, or removal of the office-holder.

\section{The functions of ordained ministers}

1. Ordained ministers must be duly authorised by their church to exercise ministry.

2. Ministers are to preach the Word of God, teach the faith, administer the sacraments, and provide pastoral care.

3. Ministers should fashion their ministry after the example of Jesus Christ.

4. Ministers must lead their private lives in a manner which befits their sacred calling. 
5. Ministers may engage in such other occupations, including offices held beyond the local church, as are not forbidden by church law or competent authority.

6. Ministers are accountable for the exercise of their ministry to the competent authority in the manner prescribed by law.

\section{The exercise of oversight}

1. Oversight is an essential of ecclesial order.

2. Oversight is exercised by such authority as is designated by law.

3. A church may have a system of international oversight or leadership.

4. A minister has such international functions of oversight or leadership as are permitted by law.

5. International church offices include those of pope, patriarch, primate, president, moderator, or general secretary.

6. Those who exercise international oversight or leadership are appointed or elected to that office by competent ecclesial authority.

7. A church may assign to such an office a coercive jurisdiction or a moral or persuasive authority.

\section{SECTION IV: CHURCH GOVERNANCE}

All the churches have institutions for their governance. Their functions may be legislative, administrative (or executive), or judicial. These institutions may exist at a variety of levels - local, regional, national, or international - depending on the polity of the church in question.

\section{Systems of church polity}

1. Christ is the ultimate head of the Church universal in all its manifestations.

2. A system of government used by a church reflects its conception of divine law.

3. A church should have institutions to legislate, administer, and adjudicate for its own governance.

4. An ecclesial institution has such power, authority, or jurisdiction as is assigned to it by law.

5. An ecclesial institution must comply with the law and may be subject in the exercise of its functions to such substantive and procedural limitations as may be prescribed by law.

6. Ecclesial institutions may be organised at international, national, regional, and/or local level. 


\section{International ecclesial communities}

1. An ecclesial tradition may have an international organisation in the form of a church, communion, federation, conference, alliance, or other global association.

2. An international ecclesial community has such institutional structure as may be constituted by or assigned to it under its doctrine and law.

3. An international ecclesial institution is composed of such persons on such terms of tenure as are assigned to it in accordance with its own juridical instruments.

\section{National church structures}

1. An ecclesial tradition may have a national organisation.

2. A church or other ecclesial community organised at national level may have such institutional structure as is prescribed by the regulatory instruments applicable to it.

3. The autonomy and functions of a national ecclesial entity, and its conference, synod, council, or other form of central assembly, may include the authority to legislate, administer, and adjudicate on matters within its competence.

4. A national ecclesial assembly or other such institution is composed of such members of the faithful as are elected or otherwise appointed to it in accordance with law.

\section{Regional church structures}

1. National ecclesial entities may have regional structures.

2. Regional ecclesial organisations may be in the form of a diocese, eparchy, synod, district, classis, presbytery, association, or other regional unit.

3. A regional ecclesial unit may have such institutions, in the form of a synod, council, classis, presbytery, or other assembly, as are prescribed by the law applicable to it.

4. A regional institution exercises such authority and functions as are conferred on it by the ecclesial community to which it belongs or the constituent churches associated with it.

5. A regional ecclesial assembly or other such institution is composed of such members of the faithful as are elected or otherwise appointed to it by those competent to do so under the law.

\section{The local church}

1. Regional ecclesial units may be divided into or constituted by local churches or congregations existing at the most localised level of church life. 
2. A church organised locally may be in the form of a parish, circuit, congregation, or other ecclesial unit.

3. A local church, its assembly and other institutions, such as a council, meeting, session, or other body, has such authority and functions as are lawfully inherent to it or conferred upon it by the institutions of the wider ecclesial entity to which it belongs.

4. The assembly of a local church is composed of those members of the faithful who are lawfully elected or otherwise appointed to it.

5. All ecclesial units at each level are interdependent.

\section{SECTION V: CHURCH DISCIPLINE}

All the churches have a system of discipline, the administration of which is regulated by norms which deal with the purpose and scope of discipline and processes to enforce it.

\section{Ecclesial discipline}

1. A church as an institution has the right to enforce discipline and to resolve conflicts amongst the faithful.

2. The right to exercise discipline has a variety of foundations including divine and spiritual authority.

3. A church may exercise discipline in relation to both lay and ordained persons to the extent provided by law.

4. The purpose of discipline is to glorify God, to protect the integrity and mission of the church, to safeguard the vulnerable from harm, and to promote the spiritual benefit of its members.

5. Discipline is exercised by competent authority in accordance with law.

\section{Informal dispute resolution}

1. Ecclesiastical disputes may be settled by a variety of formal and informal means including administrative process.

2. The competent authority may settle the matter in a process short of formal judicial process in the manner and to the extent provided by law.

3. Anyone with a sufficient interest in the matter may challenge a decision by recourse to the relevant and competent authority.

4. Visitation is exercised pastorally by a regional or other competent authority in relation to the local church or other such entity in the manner and to the extent provided by law.

5. The aim of visitation is to monitor, affirm, and improve the life and discipline of the entity visited. 


\section{Church courts and tribunals}

1. A church may have a system of courts, tribunals, or other such bodies to provide for the enforcement of discipline and the formal and judicial resolution of ecclesiastical disputes.

2. Church courts, tribunals, or other such bodies may exist at international, national, regional, and/or local level to the extent permitted by the relevant law.

3. The establishment, composition, and jurisdiction of judicial bodies are determined by the law applicable to them.

4. Church courts, tribunals, and other such bodies are established by competent authority, administered by qualified personnel, and may be tiered in terms of their original and appellate jurisdiction.

5. Church courts, tribunals, and other bodies exercise such authority over the laity and ordained ministers as is conferred upon them by law.

\section{Due process}

1. Every effort must be made by the faithful to settle their disputes amicably, lawfully, justly, and equitably, without recourse in the first instance to church courts and tribunals.

2. Formal process is mandatory if church law or civil law require it.

3. Judicial process may be composed of informal resolution, investigation, a hearing, and/or such other elements as may be prescribed by law including an appeal.

4. Christians must be judged in the church according to law applied with equity, and disciplinary procedures must secure fair, impartial, and due process.

5. The parties, particularly the accused, have the right to notice, to be heard, to question evidence, to an unbiased hearing, and where appropriate to an appeal.

\section{Ecclesiastical offences and sanctions}

1. A church may institute a system of ecclesiastical offences.

2. Ecclesiastical offences and defences to them are to be clearly defined in writing and a court, tribunal, or other body acting in a judicial capacity must give reasons for its finding of breach of church discipline.

3. A church has a right to impose spiritual and other lawful censures, penalties, and sanctions upon the faithful provided a breach of ecclesiastical discipline has been established.

4. Sanctions should be lawful and just. They may include admonition, rebuke, removal from office, and excommunication. They may be applied to the laity, clergy, and office-holders to the extent provided by 
law. Their effect is withdrawal from some of the benefits of ecclesial life. Sanctions are remedial or medicinal.

5. A church may enable the removal of sanctions.

\section{SECTION VI: DOCTRINE AND WORSHIP}

Each church teaches as its doctrine on matters of faith and practice. The doctrine of a church is rooted in the revelation of God as recorded in Holy Scripture, summed up in the historical Creeds, conveyed in tradition, and expounded in instruments, texts, and pronouncements issued by persons and institutions with lawful authority to teach.

\section{The definition of doctrine}

1. The doctrinal instruments of churches may have elements which themselves may generate norms of conduct.

2. The doctrines of a church may be interpreted and developed afresh to the extent and in the manner prescribed by law.

\section{Proclamation of the faith}

1. The proclamation of the Word of God is a fundamental action of the church and a divine imperative incumbent on all the faithful.

2. A church has the right and the duty to instruct the faithful and proclaim the Gospel.

3. Preaching is inherent to ordained ministry.

4. Authorised persons may deliver sermons or other forms of preaching for the glory of God, the edification of the people, and the exposition of church doctrine.

5. Biblical texts must be treated respectfully and coherently, building on tradition and scholarship so that scriptural revelation may continue to illuminate, challenge, and transform thinking and doing.

\section{Doctrinal discipline}

1. A church has a right to enforce its own doctrinal standards and discipline.

2. The faithful should be taught and encouraged to believe church doctrine.

3. Ordination candidates and others may be required to subscribe, assent, or otherwise affirm their belief in or loyalty to the doctrine of their church.

4. The faithful should respect, honour, and uphold the doctrine of their church.

5. Any person who offends church doctrine may be subject to disciplinary process. 
6. A church has the right to determine the limits of permissible theological opinion, and to interpret its own doctrine and doctrinal standards.

\section{The nature and forms of worship}

1. The worship of God is a fundamental obligation of a church.

2. Worship enables an intimate encounter between a church corporately and the faithful individually with the presence of God.

3. Each church and those bodies within it which are competent to do so may develop liturgical texts or other forms of service for the public worship of God provided these are consistent with the Word of God and church doctrine.

4. The use of a particular form of service must be authorised.

5. Forms of service may be found in a book of rites or liturgy, a book of common prayer, a directory of worship, or other instrument.

6. Service books may include rubrics or other directions to facilitate worship.

\section{The administration of public worship}

1. A church must provide for public worship.

2. Ordained ministers are particularly responsible for the conduct of public worship in accordance with the authorised forms of service.

3. Regular attendance at divine worship, particularly on the Lord's Day, is an expectation on the faithful.

4. The administration of worship in the local church is subject to supervision by those authorities designated by law to provide this.

\section{SECTION VII: THE RITES OF THE CHURCH}

All the churches have rites of passage which mark the stages in the spiritual life of the Christian. Certain churches call some rites sacraments and others call them ordinances.

\section{Baptism}

1. Baptism is divinely instituted.

2. A church may call baptism a sacrament or an ordinance.

3. Baptism constitutes incorporation of a person into the Church of Christ.

4. Baptism is validly administered with water in the name of the triune God.

5. Baptism should be administered ordinarily in public in the presence of the faithful by an ordained minister but extraordinarily in cases of necessity by a lay person. 
6. Baptism in a church may be of infants or adults to the extent prescribed by its law.

7. A church may impose conditions for admission to baptism.

8. A church should nurture the baptised person in the faith.

9. Baptism should be susceptible to proof.

10. Baptism cannot be repeated.

\section{Confirmation and profession}

1. A church may make provision for a further rite accompanying or following baptism which may be styled confirmation or profession of faith.

2. Candidates may undergo preparation and instruction prior to the administration of this further rite which should be administered in accordance with the practice of the church.

\section{The Eucharist, Holy Communion or Lord's Supper}

1. The Eucharist, Holy Communion or Lord's Supper is instituted by Christ.

2. The Eucharist and receiving of Holy Communion are central to ecclesial life.

3. The faithful should participate in the Eucharist regularly.

4. The faithful should receive Holy Communion regularly.

5. The Eucharist is presided over by such persons as are lawfully authorised.

6. The Eucharist should be celebrated in an authorised place.

7. A church should provide for the reception of Holy Communion by the sick.

8. The elements for the celebration of Holy Communion are bread and wine.

9. A church is entitled to make provision with regard to admission to the Eucharist.

\section{Marriage}

1. The foundation of marriage is a lifelong union between one man and one woman.

2. Marriage is instituted by God.

3. Marriage is for the well-being of the spouses.

4. To be married validly in the eyes of the church, the parties must satisfy the conditions prescribed by church law and should be instructed in the nature and obligations of marriage.

5. Marriage is celebrated in the presence of an authorised person.

6. Marriage should be registered. 
7. A marriage is ended by the death of one of the spouses and may be dissolved when so determined by competent authority.

\section{Confession}

1. A church may practise private confession and absolution in the presence of an ordained minister to the extent that this is permitted by the law of that church.

2. The seal of the confessional is inviolable, save as may be provided by the law of a church.

3. A duty of confidentiality attaches to the exercise of ministry to the extent provided by law.

\section{Funerals}

1. The faithful who have died should be given a church funeral according to the norms of law.

2. Disposal of human remains may be either by burial or by cremation accompanied by the administration of any service authorised for lawful use in a church.

\section{SECTION VIII: ECUMENISM}

Ecclesial communion between two or more churches of different traditions exists when a relationship is established in which each church believes the other to hold the essential marks of the Church universal. Full communion involves the mutual recognition of unity in faith, sacramental sharing, the mutual recognition and interchangeability of ministries, and the reciprocal enjoyment of shared spiritual and pastoral resources. Partial communion is an ecclesial relationship in which at least one but not all the elements of full communion is present. The extent and terms of ecclesial communion or other relationship between churches of two or more different traditions may be set out in a constitutional union, concordat, covenant, or other instrument agreed between the participant churches. The establishment of ecumenical agreements is an exercise of autonomy by a church in the form of collaborative ecumenical norm-making which may be prescriptive or aspirational.

\section{The Church universal}

1. There is one, holy, catholic, and apostolic Church.

2. Christ bestows unity on the Church, the Body of Christ.

3. A church has such relationship to the Church universal as is prescribed in its doctrine and law.

4. The unity of the Church universal is impaired but not destroyed by the denominational division of churches. 


\section{The nature of ecumenism and the ecumenical obligation}

1. Each church should promote visible unity amongst the separated churches.

2. Each church should promote the ecumenical movement through active dialogue and cooperation.

3. The purpose of ecumenism is greater ecclesial communion.

4. Ecumenical activity must be in accordance with the law of the ecumenical partners involved so that the discipline of each is respected.

5. The law of a church should protect the marks of the Church universal and define what ecclesial communion and reciprocity is possible.

\section{Institutional structures for ecumenism}

1. The regulation and authorisation of ecumenical activity are in the keeping of the competent authority of a church.

2. The competent authority of a church may be assisted by commissions and other advisory bodies in the ecumenical enterprise.

3. A church should provide for the ecumenical formation of the faithful.

\section{Ecclesial, ministerial and sacramental communion}

1. An agreement to establish ecclesial communion between two or more churches does not of itself affect the legal relationship between them and other churches not party to it.

2. The validity of an act performed in a church is determined by that church and recognition of such validity by another church is a matter for that other church.

3. Norms about ecumenism concerning the administration of the sacraments, mixed marriages, and sharing property are supplementary to general rules which confine such facilities to the enjoyment of the faithful within the ecclesial tradition which created those norms.

\section{Structural communion}

1. A church is free to determine whether to participate in existing international, national, regional, or local ecumenical arrangements.

2. A church may incorporate in its own law the terms of an ecumenical agreement.

3. Ecumenical agreements may be varied only with the agreement of the participant churches.

\section{SECTION IX: CHURCH PROPERTY}

The juridical instruments of the churches all contain elaborate rules which apply to church property and finance, including the use and maintenance of church 
buildings and the offerings of the Christian faithful. The idea of Christian stewardship is fundamental.

\section{The ownership of property}

1. A church has the right to acquire, administer, and dispose of property.

2. A church and/or institutions or bodies within it may seek legal personality under civil law to enable ownership of property.

3. A church may have rules about the acquisition, ownership, administration, sale, or other form of disposal of church property.

4. A church may have in place provision for its own dissolution or that of institutions or bodies within it and for the distribution of property on dissolution.

5. Property which vests in institutions is held on trust for the benefit of the church and its work and such institutions are required to exercise proper stewardship of that property.

\section{Sacred places and objects}

1. A church may dedicate or otherwise set aside a building or other space, prescribed objects, and other forms of property, to worship and other sacred purposes.

2. A place of worship, or other space, or sacred object, must be used in a manner which is consistent with its dedication.

3. Responsibility for the use, care, and maintenance of sacred places and objects vests in a designated person or body.

4. Oversight of the administration of church property vests in competent ecclesiastical authority and a periodic appraisal of its condition may be the object of a lawful visitation.

\section{The control of finance}

1. A church has the right to make rules for the administration and control of its finances.

2. The civil law applicable to financial accountability must be complied with.

3. A church must ensure sound financial management including the framing and approval by competent authority of an annual budget.

4. A church should provide, with regard to each entity within it, for the keeping of accounts for approval by a competent authority.

5. A church must ensure that financial accounts are audited annually by qualified persons in order to promote proper stewardship in the church. 


\section{Lawful income}

1. A church has a right to receive funds.

2. The faithful must contribute financially, according to their means, to the church's work.

3. The officers of a church should encourage the faithful in the matter of offerings and collect and distribute these as prescribed.

4. The local church and other entities may be required by competent authority to make a financial contribution to meet the wider institutional costs and needs of the church.

5. A church which invests money should do so prudently and in ventures which are consistent with the ethical standards of the church.

\section{Ecclesiastical expenditure}

1. A church should require the designated institutions or bodies within it to insure church property against loss.

2. A church should support and sustain those engaged in ministry according to their need and circumstance.

3. A church should make suitable provision for ordained ministers who are in ill-health and for those who retire.

\section{SECTION X: CHURCH AND STATE RELATIONS}

The churches have a wide variety of legal experiences in terms of their relationship to or institutional separation from the States in whose territorial boundaries they function.

\section{Church-State relations}

1. A church should cooperate with the State in matters of common concern, but each is independent in its own sphere.

2. The faithful may participate in politics save to the extent prohibited by church law.

3. Cooperation between a church and the State may be exercised on the basis of:

(1) The establishment of, or other formal relationship between, a church and the State;

(2) An agreement or civil legislation negotiated freely with the State;

(3) The juridical personality which a church or institutions within it may enjoy under civil law;

(4) The registration of a church in accordance with the provisions of any applicable State law; 
(5) The fundamental institutional autonomy of a church in carrying out its lawful objects and its freedom in these areas from intervention by the State.

\section{Human rights and religious freedom}

1. All humans, having been created in the image of God, share an equality of dignity and fundamental human rights.

2. A church should protect and defend human rights in society for all people.

\section{Social responsibility}

1. A church should promote social justice.

2. The faithful should promote social justice and charitable work as regulated by their church.

\section{Public institutions}

1. A church may promote the teaching of Christianity in State schools.

2. Christian teaching provided in State schools by church entities and persons is a matter of cooperation between the relevant and competent church and civil authorities.

3. A church should avail itself of the opportunities under civil law for the provision of spiritual care in public institutions, which include hospitals, homes, prisons, and the armed forces.

4. A church may seek financial assistance from the State in the provision of spiritual care in public institutions. 